gritos, por movimientos rítmicos; pero el hombre se refinó, halló otros medios de expresión más directos, aumentó su cultura y su auditorio también la aumentó, cambió el ambiente y fué necesario recurrir a otras formas de significación para expresar lo mismo; sí, lo mismo, porque entre un hombre primitivo inspirado y un poeta actual inspirado, no hay sino una diferencia de tiempo y de calidad: ambos expresan lo que sienten, aunque de distinto modo. El poema, que al principio fué un mimograma, es hoy un caligrama, un logograma. Y si a este logograma o caligrama se le añadieron reglas, que si ayudaron a hacerlo más comprensible y más aprehensible a la gente, desvirtuaron en cambio su valor íntimo y profundo de expresión sensible, su gestación y generación es idéntico al mimograma de ayer o de hace siglos. No ha podido ser variada, no podrá cambiársela nunca. La poesía de hoy intenta desprender a la obra poética de aquello que se le ha impuesto: métrica, ritmo, rima, volviéndole a dar su vuelo primitivo, solamente regidc por sus propias leyes. Seguramente lo logrará, quizá ya lo ha logrado.- I A N U E L R O J S.

\title{
Por las grises ciudades del norte de Bélgica
}

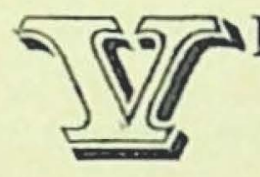

IDA de cenizas es recorrer estos puentes y estos canales y contemplar estas flechas y estas murallas puntiagudas al borde de las aguas quietas y negruzcas. Nunca la naturaleza, como en ellas, fué un mejor marco para el arte y nunca el arte cumplió en forma más definitiva su papel histórico dejando viva, eterna y palpitante toda una época desaparecida.

Todo ha quedado como si fuera ayer. Paseándonos por el Quai aux Herbes o por el Quai au Blé, de Gante, podemos, sin forzar la imaginación, reconstruir fielmente la Edad Media comercial, la de una oligarquía burguesa e industrial, dura y orgullosa. Siguiendo la Place du Beffroi tenemos la Edad Media mística y religiosa y si continuamos vagabundeando algunas calles más allá, nos encontraremos bruscamente con la Edad Media guerrera simbolizada en el castillo de los condes de Flandes. Todo en el espacio de unos pocos metros.

Tienen estas viejas ciudades flamencas el particular encanto de sabernos a algo nuevo por lo poco popularizado del estilo, fuera de su lugar de origen. Sus casas primitivas cubiertas de

Atenea.-39 
ventanas encierran una ingenua sencillez que nos hace recordar las construcciones de los niños en los juegos de cubos y palitos.

\section{BRUJAS}

Brujas fué en los siglos XIV y XV el centro comercial más importante del norte de Europa. Su población que hoy es de 52 mil habitantes, lo era de 75 mil. En este tiempo venían los barcos de todas las ciudades de la Hansa a aumentar su popularidad y su riqueza. Hoy la arena que ha cubierto su gran canal ha desviado los navíos hacia otros puertos, y Brujas se sume lentamente en la pobreza y la quietud.

Llego a ella ya concluida la saison de los turistas y sólo el eco responde a mis pasos por estas calles que en los tiempos de Felipe el Bueno, engalanados sus balcones de flores y tapices, eran recorridas por las más suntuosas cabalgatas de la época. Cuenta Taine que cuando el Delfín entró en la ciudad, ochocientos mercaderes de diversas naciones salieron a su encuentro vestidos todos de seda y terciopelo. En otra ceremonia apareció un duque, jinete en un caballo cuya silla y arreos estaban cubiertos de piedras preciosas; nueve pajes con armadura de orfebrería junto a él, y uno de dichos pajes llevaba una celada que decíase valer cien mil coronas de oro. En otra circunstancia se supone que el duque llevaba en sus adornos pedrerías que valían un millón.

Una armonía de cariliones viene a interrumpir este rememorar de alegrías pasadas.

\section{MEMLING}

No creo que haya un solo turista de paso por la ciudad, aun durante una hora, para quien la existencia del pintor Juan de Memling pase inadvertida. Las reproducciones de sus cuadros atestan las vitrinas y sus obras originales son en verdad el mayor atractivo artístico de la ciudad. Este artista, cuya nacionalidad es discutida, surge en Brujas hacia 1467. Ahí vivió la declinación de un siglo, de una era y la de su patria adoptiva. Vió pasar los días fastuosos de los duques, y sus filtimos años transcurrieron en medio de las turbaciones, en las alternativas de sumisión y de revuelta del reinado de María de Borgoña. Sobresaltos convulsivos de un particularismo que, des- 
pués de haber hecho la prosperidad de la vieja comuna, la llevó inexorablemente a la ruina.

Ciudadano del borrascoso municipio-dice un comentarista-, burgués respetado, participó sin duda de los intereses y las pasiones de esta población, que fueron hasta el extremo en la persecución del lujo, de su voluntad política y de sus obras de devoción. Almas desenfrenadas, lanzadas ya a los excesos de la sensualidad, ya a los del misticismo; igualmente dispuestas a los ásperos tráficos del mercado que a los azares de la batalla y a la oración de la capilla.

Pero las agitaciones externas, las corrupciones del emporio cosmopolita, la arrogancia de sus opulencias, las querellas del oficio, no dejaron rastros en la obra del maestro. No lo invadió la vida profana y su arte ha quedado, como el del Angélico, recluido, separado del mundo. Si se considera la época en que Memling trabajó, se pensará que la atravesó sin conocerla, y sería un error. Su arte es lo más íntimo, lo más escondido de esta época.

Las imágenes que crea satisfacen las supremas aspiraciones de sus conciudadanos: ofrece a esas creaturas impulsivas las figuras de bondad, de amor y de perdón, delante de las cuales caerán de rodillas, para pedirles socorro y ayuda en su ansiedad.

Memling vive en el hospital San Juan, en el que pinta sus mejores obras: El matrimonio místico de Santa Catalina, La adoración de los Magos, La Virgen con el Niño, síntesis admirables de dominio pictórico, de comprensión espiritual y de gracia hecha poesía en la línea y el color.

El tipo general de la virgen de Memling es de un ilimitado encanto que lleva a la alegría y la ternura. El gesto de María en La Nativité extendiendo sus brazos al niño Jesús habla de un mundo súbitamente hecho dulzura. Su fragilidad va en emocionante protección hacia el cuerpo pequeñito que provoca el amor. Y surge de este cuadro como de todos los demás la impresión clara y distinta de una detención del tiempo y de los acontecimientos ante una fuerza espiritual. Es el reposo sin laxitud; es la quietud fuerte y templada, inmovilidad que nos habla de comunión con lo absoluto. Si examinamos un momento los retratos de IViemling, por ejemplo el de María Morel, hermética e inquietante, de ojos agudos y helados, sentiremos que el rostro físicamente inexpresivo, en el sentido de los gestos, tiene un relieve de profunda sugestión espiritual. Son la representación de esta ciudad que el poeta clasificara de «Brujas la muerta» y que es sólo la máscara fría de un ardor abstracto. 


\section{TIPOS}

Lo que tan sólo ha muerto de verdad es la alegría, las pequeñas derivaciones de la vida fácil o agradable. Así encontramos muy comúnmente dos tipos de gente muy marcados: primero el tipo para quien la vida es una sucesión de días iguales y que parece no contemplar sino el más pequeño pedazo en el espacio: Tiene los ojos fijos y pequeños, muy junto a la nariz y muy bajas las cejas. Camina, actúa y trabaja en un semi-sonambulismo. Se diría que le es innecesaria la conciencia, sabiéndose bajo la guía del instinto. El otro parece no contemplar nada y sigue con igual tranquilidad que el primero la sucesión de los dias pero hay en su aparente nulidad cierta fuerza visual que hace pensar en una contemplación mística.

Ambos son severamente tristes y llegar hasta ellos sería como sumergirse en estos canales de aguas negras y quietas que jamás muestran su fondo.-M A R A VERGARA.

\section{Crónica de espectáculos}

\section{LA CRÍTICA - EL COMERCIO - LOS PRECIOS - LOS AVISOS}

( 1 ON frecuencia se dice que en Chile es ejercida la crítica teatral con propósitos personalistas; y esto no corresponde a la realidad. La pobreza de espectáculos a que vivimos sometidos no ofrece valores que analizar, ni relieves que merezcan ser destacados. Las obras se estrenan tarde y mal; las novedades no nos son conocidas como tales más que de nombre y nada nos aparta de la rutina y los métodos ejercitados desde la época en que adquirimos uso de razón y oímos hablar de Echegaray. Nuestros bataclanes son conjuntos misérrimos de niñas fofas; los cines sufren las consecuencias del industrialismo que ha introducido el género parlante en los Estados Unidos; y el público, en suma, sin saber a dónde ir, se mete en cualquier parte, con el solo objeto de pasar el rato, mientras el crítico ha de dedicarse necesariamente a anotar los progresos-y generalmente los retrocesos-experimentados por tal o cual actor. Ha desaparecido la interpreta- 